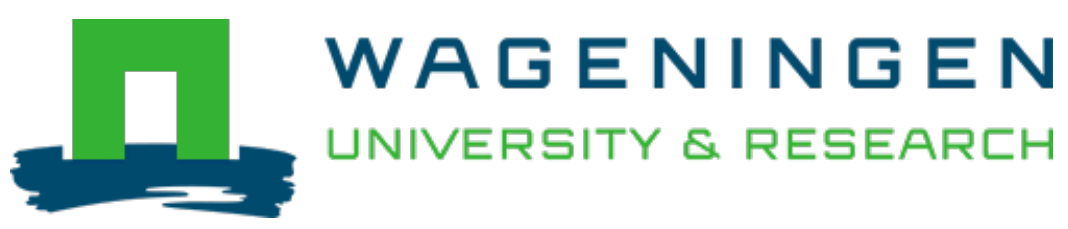

\title{
An observational assessment of Australian apple production practices for microbial control
}

\section{Food Control}

Frankish, Elizabeth J.; Bozkurt, Hayriye; Ross, Thomas; Phan-Thien, Kim Yen; Luning, Pieternel A. et al https://doi.org/10.1016/j.foodcont.2020.107767

This article is made publicly available in the institutional repository of Wageningen University and Research, under the terms of article $25 \mathrm{fa}$ of the Dutch Copyright Act, also known as the Amendment Taverne. This has been done with explicit consent by the author.

Article 25 fa states that the author of a short scientific work funded either wholly or partially by Dutch public funds is entitled to make that work publicly available for no consideration following a reasonable period of time after the work was first published, provided that clear reference is made to the source of the first publication of the work.

This publication is distributed under The Association of Universities in the Netherlands (VSNU) 'Article $25 \mathrm{fa}$ implementation' project. In this project research outputs of researchers employed by Dutch Universities that comply with the legal requirements of Article $25 \mathrm{fa}$ of the Dutch Copyright Act are distributed online and free of cost or other barriers in institutional repositories. Research outputs are distributed six months after their first online publication in the original published version and with proper attribution to the source of the original publication.

You are permitted to download and use the publication for personal purposes. All rights remain with the author(s) and / or copyright owner(s) of this work. Any use of the publication or parts of it other than authorised under article $25 \mathrm{fa}$ of the Dutch Copyright act is prohibited. Wageningen University \& Research and the author(s) of this publication shall not be held responsible or liable for any damages resulting from your (re)use of this publication.

For questions regarding the public availability of this article please contact openscience.library@,wur.nl 


\title{
An observational assessment of Australian apple production practices for microbial control
}

\author{
Elizabeth J. Frankish ${ }^{\text {a,b }}$, Hayriye Bozkurt ${ }^{\text {a, * }}$, Thomas Ross ${ }^{\mathrm{b}}$, Kim-Yen Phan-Thien ${ }^{\text {a }}$, Pieternel \\ A. Luning ${ }^{c}$, Tina L. Bell ${ }^{a}$, Robyn McConchie ${ }^{a}$ \\ ${ }^{a}$ School of Life and Environmental Sciences, Faculty of Science, University of Sydney, NSW 2006, Australia \\ ${ }^{\mathrm{b}}$ Tasmanian Institute of Agriculture, University of Tasmania, Private Bag 98, Hobart, Tasmania 7001, Australia \\ ${ }^{\mathrm{c}}$ Food Quality and Design Group, Department of Agrotechnology and Food Sciences, Wageningen University, P.O. Box 17, 6700AA Wageningen, the Netherlands
}

\section{A R T I C L E I N F O}

\section{Keywords:}

Apples

Packhouse

Food safety controls

Microbial risk assessment

Risk management

\begin{abstract}
A B S T R A C T
Food safety management criteria are often described in general terms rather than specific actions and potentially introduces subjectivity to interpretation and implementation. In the tree fruit sector, management systems would be more useful if developed with specific reference to production and processing practices used. There is insufficient evidence that requirements for the Australian tree fruit industry are appropriate to control foodborne pathogen contamination of ready-to-eat products. Thus, the purpose of this study was to explore industry interpretations of food safety guidelines by describing the application of controls in Australian orchards and packhouses and to evaluate production practices by characterising potential microbial risks in the apple industry, quantifying microbial load in wash water and fruit, and assessing fruit quality as indicators. Thirteen orchards and packhouses across Australia were visited from July 2016 to April 2018 to observe apple orchard practices, packhouse systems, wash water controls, general hygiene and to evaluate the presence of Escherichia coli, Salmonella spp. and Listeria spp. on multiple apple cultivars. The assessment revealed that the inconsistent application of water sanitation resulted in variable control of wash water quality and hygiene, but the prevalence of pathogens on apples was less than $2 \%$. Variation in practices could increase the risk of foodborne illness to consumers if contamination occurs. The Australian apple industry could benefit from a better understanding of effective risk mitigation strategies, consistent industry application of food safety controls and improved evidence of controls achieving desired food safety outcomes.
\end{abstract}

\section{Introduction}

Even though growers use good agricultural practices and comply with various food safety standards, transmission of foodborne illness via fresh fruits and vegetables has been identified as an emerging issue in Australia (Food Standards Australia New Zealand FSANZ, 2020) due to an increased number of foodborne incidents (Butler, Pintar et al., 2016).

Apples are typically consumed raw (APAL 2016) without a processing step to inactivate pathogens; hence, pre- and post-harvest activities need effective management to minimise contamination by microbial pathogens. In the United States in 2014 an outbreak of listeriosis from caramel apples, resulting in 35 illnesses with $20 \%$ mortality (Angelo, Conrad et al., 2017), alerted the apple industry to potential risks in the supply chain and raised questions concerning control of hazards in orchards and packhouses.
As the requirements for certification of food safety management increase, risk-based evidence of their effectiveness is needed. Fresh fruit microbial risk assessments (MRA) (Bassett \& McClure, 2008; Duffy \& Schaffner, 2002; Duvenage \& Korsten, 2017) and additional studies identified the most likely sources of contamination of fruit as birds (Duffy \& Schaffner, 2002), animals and water (Park, Szonyi et al., 2012; Suslow, Oria et al., 2003), food handlers (pickers) (Food and Drug Administration (FDA 1998), Food and Agriculture Organisation and World Health Organisation (FAO and WHO 2008), European Food Safety Agency (EFSA 2017)), equipment (EFSA 2017; FDA 1998) and dust (Burnett, Chen et al., 2000; Kumar, Williams et al., 2017). Inadequately sanitised wash water and poor hygiene in packhouses have also been associated with outbreaks (Garner \& Kathariou, 2016; Gibbs, Pingault et al., 2009). Listeria monocytogenes survives on apples (Salazar, Carstens et al., 2016) and, together with Escherichia coli O157:H7 and

\footnotetext{
* Corresponding author.

E-mail address: hayriye.bozkurt@sydney.edu.au (H. Bozkurt).
} 
Salmonella spp., can grow on damaged apple tissue (Allegre, Abadias et al., 2010; Leverentz, Conway et al., 2003; Riordan, Sapers et al., 2000).

In the Australian apple industry, approaches to MRA to develop risk management, subsequent implementation of controls, and their effect on food safety have not been investigated. Although the prevalence of foodborne pathogens on Australian apples is low (Department of Agriculture, 2020), this study aimed to identify potential gaps in microbial risk management in apples in the context of current orchard and packhouse food safety management systems in Australia. The approach used was to review current operations and their controls in practice in the Australian apple industry and their potential effect on food safety assessed by hygiene performance and MRA.

\section{Materials and methods}

\subsection{Selection and characterization of study sites}

Five orchards (O1-O5) and eight packhouses (P1-P8) in Australia were visited from July 2016 to April 2018 (Table 1). Sites were selected in collaboration with industry experts from Apple and Pear Australia Ltd. (APAL), to represent industry diversity in growing region, size, operational system and practices. All orchards and packhouses were certified to at least one Global Food Safety Initiative (GFSI) benchmarked quality assurance standard e.g. Global G.A.P., Freshcare (Freshcare, 2019; GlobalGap, 2019) and at least one Australian retailer standard e.g. Woolworths Limited, 2013. Various packhouse processing systems and supply chains were assessed to compare operations, food safety management controls and practices.

\subsection{Field study design}

Orchards 1 to 5 participated in the observational study. However, only growers at orchards 4 and 5 were interviewed. Packhouses 1 to 8 participated in the observational study with packhouses 1 to 6 included in the microbial and quality assessment study.

\subsection{Microbial and quality assessment}

\subsubsection{Sampling scheme}

A total of six $500 \mathrm{~mL}$ wash water samples and 54 randomly selected apple samples were collected aseptically during production using

Table 1

Characterization of the orchard (O) and packhouse (P) study sites.

\begin{tabular}{|c|c|c|c|c|c|}
\hline \multirow{2}{*}{$\begin{array}{l}\text { Study } \\
\text { site }\end{array}$} & \multirow[t]{2}{*}{ Growing region } & \multirow{2}{*}{$\begin{array}{l}\text { Organisational } \\
\text { structure }\end{array}$} & \multicolumn{3}{|c|}{$\operatorname{Size}^{\mathrm{a}}$} \\
\hline & & & S & M & $\mathrm{L}$ \\
\hline $\mathrm{O} 1$ & Region A, South Australia & Independent grower & $\mathrm{X}$ & & \\
\hline $\mathrm{O} 2$ & Region A, South Australia & Independent grower & & & $\mathrm{X}$ \\
\hline $\mathrm{O} 3$ & Region A, South Australia & Independent grower & & $\mathrm{X}$ & \\
\hline $\mathrm{O} 4$ & $\begin{array}{l}\text { Region B, Western } \\
\text { Australia }\end{array}$ & Private family company & & & $\mathrm{X}$ \\
\hline $\mathrm{O} 5$ & $\begin{array}{l}\text { Region C, Western } \\
\text { Australia }\end{array}$ & Private family company & & & $\mathrm{X}$ \\
\hline P1 & Region D, Victoria & Owner/operator & & $\mathrm{X}$ & \\
\hline P2 & Region D, Victoria & Joint owner/operator & & & $\mathrm{X}$ \\
\hline P3 & Region E, Victoria & Owner, operator & $\mathrm{X}$ & & \\
\hline P4 & Region A, South Australia & Owner, operator & & $\mathrm{X}$ & \\
\hline P5 & Region A, South Australia & Cooperative & & & $\mathrm{X}$ \\
\hline P6 & $\begin{array}{l}\text { Region C, Western } \\
\text { Australia }\end{array}$ & Owner/operator & & $\mathrm{X}$ & \\
\hline P7 & $\begin{array}{l}\text { Region B, Western } \\
\text { Australia }\end{array}$ & Owner/operator & & $\mathrm{X}$ & \\
\hline P8 & $\begin{array}{l}\text { Region B, Western } \\
\text { Australia }\end{array}$ & Private family company & & $\mathrm{X}$ & \\
\hline
\end{tabular}

Packhouse capacity (number of bins): $\mathrm{S}$ small $<10,000, \mathrm{M}$ medium 10,000-25,000, L large $>25,000$.

a Orchard size (ha): S small <100, M medium 100-200, L large $>200$. standard sampling protocols (AWWA and APHA 2017; Taylor, Sofos et al., 2015) and transported to National Association of Testing Authorities (NATA) accredited laboratories by air or road within $24 \mathrm{~h}$. All samples were maintained and stored at $<10^{\circ} \mathrm{C}$. At each packhouse, one sub-surface water grab sample from a wash tank was collected and six apple samples (five apples per sample) were collected at three points pre-wash, post-wash and post-controlled atmosphere (CA) storage. Three samples per sampling point (15 apples in total) were sent for microbial testing. Three samples (of 5 apples) were assessed for quality: soluble solids concentration $\left(\mathrm{Brix}^{\circ}\right)$ and firmness (kgf) indicating ripeness, dust caking, calyx cracking and physical damage (unhealed wounds, bruising, hail, sunburn, russet) (HIA and APAL 2016, p. 102) to determine any relationship with microbial contamination. Apple grade and provenance were recorded ((not reported). Wash water treatment is reported (Table 2). Points of collection and apple variety sampled were dependent on the logistics and availability at each packhouse. Consequently, the study included seven apple cultivars.

\subsubsection{Microbial analysis methods}

For each sample, apples $(n=5)$ were cut longitudinally into eight pieces then horizontally in $1 \mathrm{~cm}$ sections and manually mixed for $1 \mathrm{~min}$ in a stomacher bag. Portions were removed for preparation of first dilutions by Stomacher (Model 400 Circulator, Seward, Norfolk, England) for $2 \mathrm{~min}$ : $10 \mathrm{~g}$ for $E$. coli in $90 \mathrm{~mL}$ Buffered Peptone Water (BPW) (Oxoid Australia), $25 \mathrm{~g}$ for Salmonella spp. in $225 \mathrm{~mL}$ BPW and $25 \mathrm{~g}$ for Listeria spp. in $225 \mathrm{~mL}$ Half Fraser Broth (Oxoid Australia).

Analysis of apple samples for $E$. coli followed ISO 16649-2 pour plate method modified by using ChromID medium (bioMerieux Perth, Melbourne) incubated at $37^{\circ} \mathrm{C}$ for simultaneous enumeration of $E$. coli and coliforms with a detection limit of $10 \mathrm{CFU} / \mathrm{g}$. The presence/absence of Salmonella spp. and Listeria spp. in samples was assessed by SureTect ${ }^{\mathrm{TM}}$ PCR (ThermoScientific ${ }^{\mathrm{TM}}$ Adelaide) providing a detection limit of 0.04 $\mathrm{CFU} / \mathrm{g}$. Water samples were tested for indicator bacteria by Australian Standard/New Zealand Standard (AS/NZS) 4276.52007 for coliforms and AS/NZS 4276.72007 for thermotolerant coliforms and E. coli using membrane filtration with a detection limit of $1 \mathrm{CFU} / 100 \mathrm{~mL}$.

\subsubsection{Quality assessment}

Assessment of apple quality was done on-site immediately after sample collection. Apples in each sample were individually assessed against industry guidelines (HIA and APAL 2016, p. 102). 'Dust caking' was defined as the presence of dirt around the stem or calyx. 'Cracking' was used to describe visible cracks around the stem end, calyx or on the skin (United States Department of Agriculture USDA, 2002). Evidence of physical damage - bruising, hail damage and unhealed wounds caused by pests or stem puncture - was noted. Brix values were measured using a refractometer and firmness was measured using a fruit penetrometer with $11 \mathrm{~mm}$ probe by quality control staff at each packhouse. Whilst equipment manufacturers varied between packhouses, the same principles for measurement were used.

\subsection{Observational study}

Sites were observed from July 2016 to April 2018 for factors contributing to foodborne pathogen risk (Brackett, 1999; FAO/WHO 2003; Suslow, Oria et al., 2003). Food safety management in orchards and packhouses was characterised and assessed based on the systematic approach of Luning and Bango et al. (2008) and modified to include the most likely microbial risk factors to apple production. Three factors of the business environment were included for context (Kirezieva and Nanyunja et al., 2013), ten items of food safety control (Luning and Bango et al., 2008) and four items of assurance activities (Luning and Marcelis et al., 2009) as indicators of microbial performance (Jacxsens and Kussaga et al., 2009) were included to obtain a snapshot of industry practices and their efficacy. A checklist developed for this purpose is provided as supplementary material. The study had two components: 
Table 2

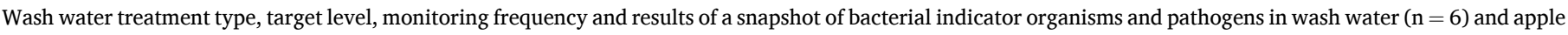
( $n=54)$ samples; each sample is five apples, from six Australian packhouses.

\begin{tabular}{|c|c|c|c|c|c|c|c|c|c|c|c|c|c|c|c|}
\hline \multirow{3}{*}{ Site } & \multirow[t]{3}{*}{ Treatment } & \multirow[t]{3}{*}{ Target } & \multirow[t]{3}{*}{ Monitoring } & \multicolumn{3}{|c|}{ Wash water microbial load ${ }^{a}$} & \multicolumn{9}{|c|}{ Apple microbial load } \\
\hline & & & & \multirow[t]{2}{*}{ Coliforms } & \multirow{2}{*}{$\begin{array}{l}\text { Thermotolerant } \\
\text { coliforms }\end{array}$} & \multirow[t]{2}{*}{ E. coli } & \multicolumn{3}{|c|}{ E. coli ${ }^{\text {b }}$} & \multicolumn{3}{|c|}{ Listeria spp. ${ }^{c}$} & \multicolumn{3}{|c|}{ Salmonella spp. ${ }^{\mathrm{c}}$} \\
\hline & & & & & & & $\begin{array}{l}\text { Pre- } \\
\text { wash }\end{array}$ & $\begin{array}{l}\text { Post } \\
\text { wash }\end{array}$ & $\begin{array}{l}\text { Post } \\
\text { CA }\end{array}$ & $\begin{array}{l}\text { Pre- } \\
\text { wash }\end{array}$ & $\begin{array}{l}\text { Post } \\
\text { wash }\end{array}$ & $\begin{array}{l}\text { Post } \\
\text { CA }\end{array}$ & $\begin{array}{l}\text { Pre- } \\
\text { wash }\end{array}$ & $\begin{array}{l}\text { Post } \\
\text { wash }\end{array}$ & $\begin{array}{l}\text { Post } \\
\text { CA }\end{array}$ \\
\hline P1 & Peroxitane & $\begin{array}{l}\text { ORP } \\
420-580\end{array}$ & Continuous & 200 & $<1$ & $<1$ & $<10$ & $<10$ & $<10$ & ND & ND & ND & ND & ND & ND \\
\hline P2 & $\begin{array}{l}\text { Chlorine } \\
\text { dioxide }\end{array}$ & $\begin{array}{l}0.1-0.3 \\
\text { ppm }\end{array}$ & Continuous & $\approx 12$ & $<1$ & $<1$ & $<10$ & $<10$ & $<10$ & ND & ND & ND & ND & ND & ND \\
\hline P3 & None & none & None & 5300 & 4000 & 4000 & $<10$ & $<10$ & $<10$ & ND & ND & ND & ND & ND & ND \\
\hline P4 & Nylate & ORP 650 & None & 11,000 & 200 & 200 & $<10$ & $<10$ & $<10$ & ND & ND & ND & ND & ND & ND \\
\hline P5 & Chlorine & $5 \mathrm{ppm}$ & Daily & $<1$ & $<1$ & $<1$ & $<10$ & $<10$ & $<10$ & ND & ND & ND & ND & ND & ND \\
\hline P6 & Chlorine & $30 \mathrm{ppm}$ & Daily & $<1$ & $<1$ & $<1$ & $<10$ & $<10$ & $<10$ & $\mathrm{D} \times 1$ & ND & ND & ND & ND & ND \\
\hline
\end{tabular}

$\mathrm{P}$ packhouse, ORP oxidation reduction potential, ppm parts per million, bromo chloro dimethyl hydrantoin

a Colony forming units per $100 \mathrm{~mL}$.

b colony forming units per $\mathrm{g}$.

${ }^{c}$ Detected (D)/not detected (ND) in $25 \mathrm{~g}$. Apple results $\mathrm{n}=3$ at each sampling point.

semi-structured interviews and a hygiene gap audit, i.e. observations of the degree of conformance to best practice based on FDA 1998, FAO/WHO 2003 and the Harmonised Australian Retailer Produce Scheme (HARPS) (HA Ltd. 2016).

\subsubsection{Semi-structured interviews}

Growers (2), operations (7) and quality assurance (8) managers were interviewed about how microbial hazards and risk mitigation strategies were identified and prioritised (food safety policy), what food safety controls were considered the most important, verification of microbial control (food safety assurance), and about challenges in implementing food safety controls. Interviewees were given time during interviews to explore these topics and responses were recorded. If information was missing or unclear on subsequent review, interviewees were later contacted by phone or email for clarification. Responses were scored 1 'poor' or 'did not meet', 2 - 'average' or 'partially met' and 3 - 'good' or 'met' based on apparent compliance with guidelines/standards (FAO/WHO 1999; FAO/WHO 2003; FPSC 2019; Freshcare, 2019).

\subsubsection{Hygiene assessment}

Preventive measures and intervention processes were assessed by gap audit. These included controls for dust contamination, animal and pest intrusion, personal hygiene (protective clothing, availability, cleanliness and utility of handwashing facilities and restrooms), equipment cleanliness and maintenance, building cleanliness, process flow and waste management. Scores were assigned as described in 2.4.1. When control was inconsistent, for example, one food handler did not wear a hairnet, a score of 2 was assigned.

\subsection{Statistical analysis of data}

Due to zero variability in data from some packhouses, all data were analysed using a Monte Carlo Kruskal-Wallis test (Kruskal \& Wallis, 1952). Personnel and building/equipment scores were combined and analysed using the equation score $=$ scored/score max $_{\text {ax }}$ and by analysis of variance (ANOVA) using an asymptotic Kruskal-Wallis nonparametric test with the null hypothesis that all results were equal at 95\% confidence. For Brix and firmness, the average measurement of the three samples was calculated before data analysis.

The study was approved by Social Sciences Human Research Ethics Committee, Research Integrity and Ethics Unit, University of Tasmania (number H0017183).

\section{Results and discussion}

\subsection{Microbial and quality assessment}

\subsubsection{Wash water}

Two of the six packhouses had $<1 \mathrm{CFU} / 100 \mathrm{~mL}$ E. coli, coliforms and thermotolerant coliforms in their wash water (Table 2). The two packhouses that monitored wash water continuously had $<1 \mathrm{CFU} / 100 \mathrm{~mL}$ for E. coli and thermotolerant coliforms, but coliforms were detected (Table 2). Packhouses without monitoring protocols in place had high levels of all microbial contaminants $(>100 \mathrm{CFU} / 100 \mathrm{~mL})$. Packhouses with wash water in compliance with current guidelines for $E$. coli (FAO/WHO 2003; FPSC 2019) used 'town' water treated with an approved sanitiser and daily monitoring (P5 and P6). However, automatic dosing or monitoring systems did not ensure the absence of all indicator bacteria suggesting that at times of high organic load (e.g. leaf litter, dust, apple sunscreen) or microbial load on apples the process could allow survival of $E$. coli. When surface water without sanitiser (P3) or rainwater without monitoring (P4) were used high levels of the target bacteria were observed, indicating a potential risk of apples contaminated with pathogens (Brackett, 1999; FDA 1998).

\subsubsection{Apples}

Sample collection points in the processing stage were more varied than anticipated (e.g. some pre-wash samples were fresh from the orchard or out of storage), however, apparently this did not affect microbial loads on apples as $E$. coli and Salmonella spp. were not detected in any samples collected (Table 2). Detection rates of $E$. coli in similar surveys are generally low (Abadias, Usall et al., 2008; van Dyk, de Bruin et al., 2016), Duvenage and Korsten (2017), (De, Li et al., 2018), although Abadias et al. (2006) found 8.3\% of apples sampled from the orchard and $13.9 \%$ post-packing had low levels of contamination. Surprisingly, we did not find $E$. coli on apples sampled from the contaminated wash water. This may indicate a low transfer rate as various studies (Pahl, Telias et al., 2013; Won, Schlegel et al., 2013; Xu, Pahl et al., 2015) report a limited relationship between bacterial counts in irrigation water and contamination on produce.

No Salmonella spp. were detected in apples sampled in this study (Table 2). Detection of Salmonella spp. on tree fruit varies (Abadias, Canamas et al., 2006; Gomba, Chidamba et al., 2016). Abadias et al. (2006) found no Salmonella spp. in a whole supply chain survey of 216 apple samples in Spain collected after CA storage but Gomba et al. (2016) found nearly 5\% contamination in tree fruit samples taken from 225 orchard and packhouse locations in South Africa. In the latter study, when either irrigation or wash water was positive for Salmonella spp., the pathogen was also detected on fruit. Although not a tree fruit, a 
survey of 117 field and packhouse tomato samples (van Dyk, de Bruin et al., 2016) failed to detect any Salmonella spp. This suggests that if the water is clean, the fruit will also be clean.

In this study, Listeria spp were detected (at $<10 \mathrm{CFU} / \mathrm{g}$ ) in only one apple sample before washing (Table 2). Listeria spp. were not detected in the same batch of apples sampled post-wash and no indicator bacteria were detected in the wash water. The wash water was treated with 30 ppm chlorine and well monitored. There are few non-outbreak related surveys for Listeria spp. for tree fruit (Abadias, Usall et al., 2008; Duvenage \& Korsten, 2017; Uchima, de Castro et al., 2008). A low detection rate of $1.8 \%(1 / 54)$ in this study was similar to that found for peaches (Duvenage \& Korsten, 2017) and consistent with other fresh produce surveys (Food Standards Australia New Zealand FSANZ, 2010). Given the source of the samples, the contamination might have been due to a dust-affected bin.

Although differences for quality parameters were found between packhouses, no significant consistent differences were apparent between fruit quality parameters and microbial detection. However, dust caking and damaged fruit were observed in all packhouses (Table 3) adding to the potential for contamination (Kenney, Burnett et al., 2001; Kumar, Williams et al., 2017; Riordan, Sapers et al., 2000) and accentuating the need to determine risk points in the operations and mitigations.

\subsection{Observational study}

Food safety management practices were explored to evaluate producer understanding and interpretation of quality control requirements and assess the potential for microbial risk. Results of interviews and hygiene assessment are combined in Table 4. 'Food safety controls' (FSC) refer to preventive activities that were documented policy at the interviewees' businesses and observed in practices. 'Food safety assurance' refers to verification of sanitiser use and microbial testing.

\subsubsection{Contextual risk factors}

Water source. Six packhouses used town water supply for washing operations, one site used rainwater and one site accessed river water for apple washing, resulting in scores 'good', 'average' and 'poor' respectively (Table 4). Irrigation water included farm dams, river and greywater, all of which are known sources of pathogens that can cause direct or indirect contamination (FDA 1998; Park, Szonyi et al., 2012). The two orchards scored were assigned 'average' because there was little observational evidence of interventions to lower risk of water-related contamination (Table 4). However, the farm dam at one orchard, filled by rainwater, was lined with plastic to reduce contamination from sediments after rainfall. While under-canopy spray irrigation and fertigation were used, which minimised direct fruit contact and thus risk from pathogens in water (FDA 1998), overhead sprinklers were used for foliar spray application and cooling apples. Dropped fruit may allow contact with irrigation water and soil, with a risk of associated pathogens transferring to fruit surfaces (Duffy \& Schaffner, 2002). Orchard
Table 4

Assessment of food safety management according to observational analysis and semi-structured interviews. Scores of 'poor', 'average' and 'good' were based on compliance assessed against guidelines. Numbers represent the number of orchards or packhouses in each assessment category. Two orchards and eight packhouses participated in the semi-structured interviews.

\begin{tabular}{|c|c|c|c|c|c|c|}
\hline \multirow[t]{2}{*}{ Feature } & \multicolumn{3}{|c|}{ Orchards } & \multicolumn{3}{|c|}{ Packhouses } \\
\hline & Poor & Average & Good & Poor & Average & Good \\
\hline \multicolumn{7}{|l|}{ Context } \\
\hline Food safety policy & - & 2 & - & - & 4 & 4 \\
\hline $\begin{array}{l}\text { Relationship with } \\
\text { suppliers }\end{array}$ & - & 2 & - & - & 8 & - \\
\hline Water source & - & 2 & - & 1 & 1 & 6 \\
\hline \multicolumn{7}{|l|}{ Food safety controls } \\
\hline Dust/soil & 1 & 1 & & 2 & 3 & 3 \\
\hline $\begin{array}{l}\text { Animal/bird/pest } \\
\text { intrusion }\end{array}$ & - & 1 & 1 & 2 & 3 & 3 \\
\hline Building design & 1 & 1 & & 1 & 4 & 3 \\
\hline Process flow & na & na & na & 1 & 4 & 3 \\
\hline Building hygiene & 1 & - & 1 & 3 & 2 & 3 \\
\hline Equipment hygiene & - & 1 & 1 & 2 & 3 & 3 \\
\hline Waste & - & - & 2 & - & 6 & 2 \\
\hline Cleaning and sanitation & - & 1 & 1 & - & 6 & 2 \\
\hline Food handler hygiene & 1 & 1 & - & 1 & 3 & 4 \\
\hline $\begin{array}{l}\text { Toilet/handwashing } \\
\text { facilities compliance }\end{array}$ & - & - & 2 & - & 2 & 6 \\
\hline \multicolumn{7}{|c|}{ Food safety assurance verification } \\
\hline \multicolumn{7}{|l|}{ Irrigation/wash water: } \\
\hline Chemical & na & na & na & 2 & 4 & 2 \\
\hline Microbial & 2 & - & - & 4 & 2 & 2 \\
\hline Fruit microbial testing & 1 & 1 & - & 2 & 3 & 3 \\
\hline $\begin{array}{l}\text { Environmental } \\
\text { swabbing program }\end{array}$ & - & 2 & - & 4 & 3 & 1 \\
\hline
\end{tabular}

Na not applicable.

and packhouse policies excluded dropped fruit at harvest, but packhouse managers indicated that control was difficult. Another unexpected pathway for contamination from water was the use of irrigation water to dampen sack covers on harvested apples for the prevention of sunburn.

\subsubsection{Food safety controls}

Dust and soil. Dust or soil control was poor in the orchard because dirt roads (Table 4) increased the potential for fruit contamination as demonstrated for Salmonella spp. and tomatoes (Kumar, Williams et al., 2017). Growers scored a 'good' rating when they sought to reduce cross-contamination to apples by using single-use plastic bin liners or daily cleaning/sanitising of picker bags. However, one grower said, "crates are often returned from wholesalers uncleaned, so fruit gets contaminated anyway". Three packhouse managers raised concern over dust and soil contaminating fruit and harvest bins, with one stating "I work on the principle of remove the dirt, remove the problem". Splash-back from muddy bins could result in cross-contamination to apples (Allende, Castro-Ibanez et al., 2017). Dirty bins and apples also increase the organic load in dump and wash tanks, reducing the

Table 3

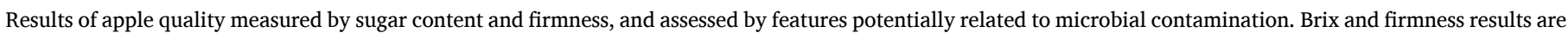
averages $(\mathrm{n}=15)$ of triplicate samples of five apples. Dust caking and physical damage results are the number of positive apples from $\mathrm{n}=15$.

\begin{tabular}{|c|c|c|c|c|c|c|c|c|c|c|c|c|}
\hline \multirow[t]{2}{*}{ Site } & \multicolumn{3}{|l|}{ Brix (\%) } & \multicolumn{3}{|c|}{ Firmness $\left(\mathrm{kgf}^{\mathrm{b}}\right)$} & \multicolumn{3}{|c|}{ Dust caking } & \multicolumn{3}{|c|}{ Physical damage (major) } \\
\hline & Pre-wash & Post-wash & Post-CA ${ }^{a}$ & Pre-wash & Post-wash & Post-CA & Pre-wash & Post-wash & Post-CA & Pre-wash & Post-wash & Post-CA \\
\hline P1 & 13.3 & 13.6 & 13.9 & 8.4 & 8.7 & 8.7 & 0 & 1 & 0 & 1 & 2 & 0 \\
\hline $\mathrm{P} 2$ & 12.2 & 14.3 & 12.2 & 8.3 & 9.3 & 8.3 & 0 & 0 & 1 & 0 & 1 & 1 \\
\hline P3 & 12.8 & 12.0 & 12.0 & 7.9 & 7.4 & 7.4 & 0 & 1 & 0 & 2 & 2 & 1 \\
\hline P4 & 13.6 & 13.6 & 13.6 & 5.9 & 5.9 & 5.9 & 0 & 0 & 1 & 1 & 1 & 1 \\
\hline P5 & 16.2 & 15.7 & 15.1 & 9.3 & 10.0 & 9.4 & 2 & 0 & 0 & 0 & 2 & 3 \\
\hline P6 & 13.0 & 13.9 & 12.3 & 8.6 & 8.6 & 8.0 & 1 & 0 & 0 & 0 & 0 & 3 \\
\hline
\end{tabular}

\footnotetext{
${ }^{\text {a }}$ Controlled atmosphere.
}

${ }^{\mathrm{b}}$ kilogram force. 
effectiveness of sanitisers (FDA 1998; Suslow, 1997, pp. 1-15) and increasing potential for pathogen survival and cross-contamination between fruit (Gil, Selma et al., 2009).

Animals and pests. Although intrusion of domestic animals was controlled, kangaroo droppings and birds were seen in orchards so an 'average' rating was assigned (Table 4), because the potential for pathogen transfer from faeces to bins during harvest was demonstrated. Native animals, rodents and sheep seen grazing adjacent to orchards were potential sources of direct and indirect faecal contamination to farm dams (Park, Szonyi et al., 2012; Suslow, Oria et al., 2003). The increased use of netting in orchards to modify climatic conditions may reduce the likelihood of bird damage thus lowering microbial risk. When assessing waste management, less decaying fruit was observed in orchards where under-tree debris was swept away to mitigate risk of rodent activity. As rodents can carry and shed pathogens (e.g. Salmonella spp.) (Kilonzo, Li et al., 2013; Meerburg, Singleton et al., 2009), reducing their prevalence through good orchard hygiene would be expected to decrease the risk of contamination of fruit on trees.

Building design and process flow. In all orchards, fruit was temporarily held in open, general storage sheds (assigned 'average' rating), providing points for pest harbourage and cross contamination to harvested apples. One site used a lean-to exposed to prevailing winds (assigned a 'poor' rating) (Table 4).

Harvested apples delivered to packhouses are placed in water dumps to float the apples through wash water tanks. Conveyor travel through drying tunnels, waxing and graders follows in various order, after which they are clean and move to the packing lines. Apple packing lines are dry areas where the risk of pathogens like L. monocytogenes is lower (Sutherland, Miles et al., 2003). The operational workflow in two packhouses with high ratings facilitated movement from packing (low contamination) to bin receival (high contamination) to prevent cross-contamination of finished product and compliance was enforced (Table 4). Low and high contamination areas were not demarcated at four packhouses where the workflow was in the opposite direction. In two packhouses direction of movement was ad hoc, lowering the rating assigned for this feature (Table 4). Failure to control people movement through facilities increases the risk of cross-contamination of finished product from dirty and wet areas (Sutherland, Miles et al., 2003, UFPA 2013).

Large packhouses offering centralised processing facilities with longer distances between fruit receival and despatch are reported to lower the likelihood of microbial contamination in wash and packing areas from dust, birds and pests (Suslow, Oria et al., 2003): However, if these facilities did not use internal walls as physical barriers to prevent cross-contamination by air, water or traffic flow they were scored "average" (Table 4).

Washing areas in all packhouses operated at ambient temperature where apples were held for up to $12 \mathrm{~h}$. Growth of pathogens, if present, would be unlikely due to low pH of apples (Wu, Gao et al., 2007) but bruised or wounded fruit that is not removed from the line can provide environments conducive to growth (Dingman, 2000; Glass, Golden et al., 2015). Storage conditions in cool rooms, typically $0-4{ }^{\circ} \mathrm{C}$ and from 0 to $2{ }^{\circ} \mathrm{C}$ under CA, inhibit growth of pathogens such as Salmonella spp. (Jay, Davos et al., 2003) and E. coli, although L. monocytogenes can survive for 5 months during cold storage (Macarisin, Sheth et al., 2019).

Building and equipment hygiene. Observation of dirt accumulation on bins, crates, brushes, grading cups and conveyor belts indicated the potential for equipment to contaminate apples (Table 4). Soil can harbour microbes (Ailes, Leon et al., 2008; FPSC 2019) and can be a source of cross-contamination in the packhouse (FDA 1998; FPSC 2019; Harris, Farber et al., 2003; Suslow, Oria et al., 2003), increasing risk of fruit contamination (Gagliardi, Millner et al., 2003). UFPA (2018) and
FPSC (2019) recommend that equipment and facilities should be designed, cleaned and sanitised to prevent cross-contamination and development of niches where pathogens can survive.

Only two packhouses cleaned their wash lines daily but procedures varied to include wipe down, air hosing or steam cleaning (Table 4). The effect on risk reduction of these practices is unknown because cleaning verification was infrequent. Ineffective sanitation contributes to fruit contamination and outbreaks (Gagliardi, Millner et al., 2003; Garner \& Kathariou, 2016; Gibbs, Pingault et al., 2009) thus, verification of cleaning and sanitising is important for risk mitigation. Pre-sizers (water flume graders), although vacuum cleaned weekly were only emptied and scrubbed every 12-18 months, so biofilms could form and be a source of pathogens as occurs in other food sectors (Kumar \& Anand, 1998; Ryu \& Beuchat, 2005).

Hygiene scores at each packhouse ranged from 'poor' to 'good' (Table 4) indicating that some controls were well managed, and others were neglected, highlighting the challenges in consistently maintaining good hygiene. There was evidence that cleaning schedules, procedures and their compliance need review in some establishments. Similarly, assessment of waste management showed that wastewater, general rubbish, and organic waste disposal was compromised. Water pooling on floors was observed at two packhouses potentially resulting in splashback to product, transfer of contaminated water through the facility and increased risk of contamination to fruit and equipment (FDA 1998, Department of Agriculture Western Australia 2002; Suslow, Oria et al., 2003) from pathogens such as L. monocytogenes (Sutherland, Miles et al., 2003).

One packhouse used ozone-generating systems to clean surfaces and air in CA rooms. Use of ozone in storage and packing facilities is well established for postharvest disease control (Smilanick, 2003). However, verification of its effectiveness for control of foodborne pathogens would be of interest to the fresh fruit industry.

Food handlers. Food safety training and staff supervision was found to present a challenge to the industry. Hand washing and use of antiseptic are required by Australian Food Safety Standards (FSANZ, 2000) but, as indicated by the ratings given (Table 4), consistent compliance was problematic despite appropriate hygiene policies being advocated. One grower commented "you can't be certain they do it" and "pickers don't think of themselves as food handlers". This suggests that not all pickers appreciated that direct hand-fruit contact introduces risk of contamination and that good personal hygiene can reduce contamination (Brackett, 1999). Other barriers for food handler hygiene were handwashing facilities or hand sanitiser not being available in all portable toilets in orchards. Gloves were not always worn, particularly in the packhouse, and when they were worn in orchards, they were sanitised only daily. Food handlers can affect the likelihood of contamination of fruit (Brackett, 1999), thus, industry-consistent personal hygiene could increase certainty of control.

Only half the packhouses paid attention to use of protective clothing, suggesting differences in risk perception. Although Australian guidelines (FPSC 2019; Freshcare, 2019) allow grower/packer discretion for glove use, as does the USA (FDA and DoHHS 2016), failure to enforce protective clothing protocols is inconsistent with best practice (FPSC 2019). The perception of the food safety 'climate' in the facility could explain less stringent control at some sites (De Boeck, Jacxsens et al., 2015). Based on poor ratings at some sites and because food handlers have been implicated in outbreaks (Machado-Moreira, Richards et al., 2019) the lack of validation, verification and monitoring of personal hygiene controls and absence of management tools to measure FSC objectives are important issues requiring attention.

Wash water. Sanitiser use in postharvest water is critical to mitigate microbial risk. The primary purpose is to prevent contamination of water and cross-contamination of apples should pathogens be 
introduced from apples and bins (Bassett \& McClure, 2008; FDA 1998). This study provided evidence of variation in wash water sanitary control and its verification (Table 2). Seven packhouses sanitised dump and wash water, consistent with best practice. Four packhouses used chlorinated pre-sizers - three with manual monitoring, one with automatic monitoring. Four packhouses washed apples before and after storage, including the site without water treatment. Multiple washes increase risk management requirements, and thus, the potential for failure. The failure of some packhouses to control their wash water quality suggests that further education and training of packhouse managers in risk assessment is needed.

Dump and wash water temperatures were not controlled or monitored in any packhouses. Apples were sometimes washed straight from the orchard when fruit temperature was high. Apple surface temperatures of $27^{\circ} \mathrm{C}$ were reported at one packhouse and one grower said fruit can reach up to $45^{\circ} \mathrm{C}$. There is risk of internalisation of pathogens if warm fruit is immersed in colder contaminated wash water (IFT and FDA 2001). Studies indicate that if the core temperature of apples is greater by 13 (Buchanan, Edelson et al., 1999) or $23^{\circ} \mathrm{C}$ (Burnett, Chen et al., 2000) than wash water pathogen uptake through the calyx is enhanced. Australian guidelines identify this risk in postharvest water use but do not provide specific temperature gradient recommendations (FPSC 2019). Temperature gradients between fruit and wash water and poor sanitary control contributed to an outbreak of Salmonella associated with rockmelons in Australia (Munnoch, Ward et al., 2009).

\subsubsection{Food safety assurance}

Verification activity was mostly poor for orchards and in the packhouse environment scores varied (Table 4) due to differences in testing frequency or absence of microbial testing. Certification systems require that verification testing of wash water be conducted at a rate commensurate with the business risk assessment (Freshcare, 2019). However, irrigation water quality was generally only assessed annually for certification compliance, indicating inappropriate risk assessment because of insufficient data to understand and describe variation in quality or likelihood of high-risk contamination events (FDA and DoHHS 2016). Cool room cleaning was verified annually by environmental swabbing for E. coli and Salmonella.

Two packhouse operators assumed that wash water microbial risk was controlled with ad hoc addition of chlorine or removal of dirt from bins, but our results showed E. coli was present at levels indicating the potential for pathogen presence in these systems (Table 2). Testing frequency varied at packhouses with no obvious link to the control system used. For example, only two packhouses tested dump water annually for E. coli. Curiously, testing town supply source water was common but untreated sources of water were not tested. Testing wash water to increase knowledge of system performance, rather than town supply, would be a better use of resources because data analysis of results could be used in risk mitigation decisions.

Microbial testing of fruit was variable with two packhouses doing no testing (assigned a "poor" rating), three packhouses testing one to two times per year ("average" rating) and three packhouses testing four times/year (good rating) (Table 4). Apples were analysed for E. coli, Salmonella spp.and L. monocytogenes. Australian retail chains have applied quality standards to apple packhouses that include microbiological criteria and fruit verification requirements (Woolworths Limited, 2013, Coles Supermarkets Australia Pty. Ltd. 2016). This has encouraged implementation of MRA and preventive actions (Premier \& Ledger, 2006). However, there was little evidence of real-time responses to changes in risk level. The only example identified in this study was increasing the number of food handlers removing damaged fruit after hail, a potential avenue for contamination (Dingman, 2000; Glass, Golden et al., 2015).

Half the packhouses verified equipment cleaning by implementing an environmental monitoring programme; but frequency of testing ranged from one to four times per year. A 'good' rating was given for more frequent verification as it provides greater assurance that microbial hazards are controlled. Samples were analysed for coliforms, E. coli, coagulase positive staphylococci, Salmonella spp. and L. monocytogenes (1 packhouse) or E. coli and Listeria spp. (3 packhouses).

Assurance activities did not correlate with the level of potential risk observed, in that less developed management and technology generally require more verification to manage risk (Kirezieva, Nanyunja et al., 2013; Luning, Marcelis et al., 2009). In this study, packhouses with less sophisticated operational systems and/or less sanitary controls did the least verification, thereby preventing use of data to assess risk and make appropriate changes. Low verification activity might be due to lack of understanding of the benefits conferred, cost, or logistics associated with sample analysis.

\section{Conclusion}

The packhouses participating in this study had low prevalence of food-borne pathogens on apples.

However, observational assessment provided evidence of very inconsistent application of hygiene controls. Although correlation between the level of hygiene control and the presence of pathogens could not be discerned and there was no relationship between microbial water quality and pathogen prevalence on apples, despite variable levels of sanitisation, an indication was obtained that pathogens enter the packhouse from the orchard, highlighting the importance of consistent and reliable hygiene control and the need for routine monitoring programs to identify contamination hotspots. Thus, this study raises questions over grower interpretation of standard audit results which are a snapshot in time, in assessing risk and suggests that auditing focused on the details of critical food safety controls like water sanitisation would be valuable.

Inadequately sanitised wash water and equipment can lead to contaminated produce and outbreaks. A low level of system verification exposes customers to risk of foodborne illness if pathogen contamination occurs and can lead to reputational risk to the industry. Where interviewee responses did not differ from observations, there was good understanding about food safety control, and sound technical understanding of wash water sanitisation resulted in good microbial control of wash water. In general, however, improved knowledge and application of risk assessment methods would benefit the industry.

Despite orchards and packhouses using analogous certification standards, food safety controls and verification (assurance) activities varied, indicating insufficient knowledge of system performance. This presents an opportunity for the industry to further investigate the effect of different approaches to food safety management and thus acquire the knowledge needed to ensure consistent outcomes are achieved from implemented controls. In this study, overall food safety evaluated by hygiene audits and microbial assessment of wash water and apples, varied from 'poor' to 'good'. This highlights the importance of more specific guidelines based on risk assessment for apples that can be easily and consistently interpreted. The lack of evidence- and outcome-based requirements in standards may be a barrier to improving industry consistency because they allow individual interpretation. Although this was a small, non-systematic study it provided valuable insight for the Australian apple industry on the range of current practices, gaps in microbial hazard control and evidence of control. While further studies should focus on the effect that variations in practices have on microbial risk, this study has highlighted the need for tools to measure food safety management performance and assist risk-based decision-making.

\section{CRediT authorship contribution statement}

Elizabeth J. Frankish: Conceptualization, Methodology, Investigation, Data curation, Writing - original draft, Writing - review \& editing. Hayriye Bozkurt: Conceptualization, Writing - original draft, Writing review \& editing, Visualization, Supervision, Project administration. 
Thomas Ross: Conceptualization, Methodology, Validation, Formal analysis, Writing - review \& editing, Supervision, Resources, Project administration. Kim-Yen Phan-Thien: Conceptualization, Methodology, Validation, Writing - review \& editing, Visualization, Supervision, Project administration. Pieternel A. Luning: Validation, Formal analysis, Writing - review \& editing, Visualization. Tina L. Bell: Conceptualization, Methodology, Validation, Writing - review \& editing, Supervision, Project administration. Robyn McConchie: Conceptualization, Methodology, Validation, Writing - review \& editing, Resources, Supervision, Project administration, Funding acquisition.

\section{Acknowledgements}

The authors thank the growers and packhouse operators who participated in this study. This work was funded by the Australian Research Council (ARC) through the ARC Training Centre Food Safety in Fresh Produce, and Apple and Pear Australia Ltd.

\section{Appendix A. Supplementary data}

Supplementary data to this article can be found online at https://doi. org/10.1016/j.foodcont.2020.107767.

\section{Conflict of interest and authorship conformation form}

-All authors have participated in (a) conception and design, or analysis and interpretation of the data; (b) drafting the article or revising it critically for important intellectual content; and (c) approval of the final version.

-This manuscript has not been submitted to, nor is under review at, another journal or other publishing venue.

-The authors have no affiliation with any organisation with a direct or indirect financial interest in the subject matter discussed in the manuscript

\section{References}

Abadias, M., Canamas, T. P., Asensio, A., Anguera, M., \& Vinas, I. (2006). Microbial quality of commercial 'Golden Delicious' apples throughout production and shelf life in Lleida (Catalonia, Spain). International Journal of Food Microbiology, 108, 404-409.

Abadias, M., Usall, J., Anguera, M., Solsona, C., \& Vinas, I. (2008). Microbiological quality of fresh, minimally-processed fruit and vegetables, and sprouts from retail establishments. International Journal of Food Microbiology, 123, 121-129.

Ailes, E. C., Leon, J., Jaykus, L.-A., Johnston, L., Clayton, H., Blanding, S., Kleinbaum, D. Backer, L., \& Moe, C. (2008). Microbial concentrations on fresh produce are affected by postharvest processing, importation and season. Journal of Food Protection, 71 (12), 2389-2397.

Allegre, I., Abadias, M., Anguera, M., Oliviera, M., \& Vinas, I. (2010). Factors affecting growth of foodborne pathogens on minimally processed apples. Food Microbiology, 27, 70-76.

Allende, A., Castro-Ibanez, I., Lindqvist, R., Gil, M. I., Uyttendaele, M., \& Jacxsens, L. (2017). Quantitative contamination assessment of Escherichia coli in baby spinach primary production in Spain: Effects of weather conditions and agricultural practices. International Journal of Food Microbiology, 257, 208-246.

American Water Works Association and American Public Health Association. (2017). AWWA, APHA. Standard methods for the examination of water and wastewater.

Angelo, K. M., Conrad, A., Saupe, A., Dragoo, H., West, N., Sorenson, A., Barnes, A., Doyle, M., Beal, J., Jackson, K. A., Stroika, S., Tarr, C., Kucerova, Z., Lance, S., Gould, L. H., Wise, M., \& Jackson, B. R. (2017). Multistate outbreak of Listeria monocytogenes infections linked to whole apples used in commercially produced, pre-packaged caramel apples; United States, 2014-2015. Epidemiology and Infection, 145, 848-856.

Apple and Pear Australia Ltd. (2016). Statistics. Retrieved 11 Sept, 2017, from http://apa 1.org.au/industry-info/apple-and-pear-statistics/.

Bassett, J., \& McClure, P. (2008). A risk assessment approach for fresh fruits. Journal of Applied Microbiology, 104, 925-943.

Brackett, R. E. (1999). Incidence, contributing factors, and control of bacterial pathogens in produce. Postharvest Biology and Technology, 15(3), 305-311.

Burnett, S. L., Chen, J., \& Beuchat, L. R. (2000). Attachment of Escherichia coli O157:H7 to the surfaces and internal structures of apples as detected by confocal scanning laser microscopy. Applied and Environmental Microbiology, 66(11), 4679-4687.
Butler, A. J., Pintar, K. D. M., \& Thomas, M. K. (2016). Estimating the relative role of various subcategories of food, water and animal contact transmission of 28 enteric diseases in Canada. Foodborne Pathogens and Disease, 13(2), 57-64.

Coles Supermarkets Australia Pty Ltd. (2016). Coles brand testing specification S25 fruit (whole). Coles Supermarkets Australia Ltd. S25. viewed 1st April 2017 https://www. supplierportal.coles.com.au/csp/wps/portal/web/Quality/AllSuppliers/Produce.

De Boeck, E., Jacxsens, L., Bollaerts, M., \& Vlerick, P. (2015). Food safety climate in food processing organisations: Development and validation of a self-assessment tool. Trends in Food Science \& Technology, 46, 242-251.

De, J., Li, Y., Sreedharan, A., Goodrich Schneider, R., Gutierrez, A., Jubair, M., Danyluk, M. D., \& Schneider, K. R. (2018). A three-year survey of Florida packinghouses to determine microbial loads on pre- and post-processed tomatoes. Food Control, 86, 383-388.

Department of Agriculture, WatE. (2020). National residue survey, viewed 1st April 2020. https://www.agriculture.gov.au/ag-farm-food/food/nrs.

Dingman, D. W. (2000). Growth of Escherichia coli O157:H7 in bruised apple (Malus domestica) tissue as influenced by cultivar, date of harvest and source. Applied and Environmental Microbiology, 66(3), 1077-1083.

Duffy, S., \& Schaffner, D. W. (2002). Monte Carlo simulation of the risk of contamination of apples with Escherichia coli 0157:H7. International Journal of Food Microbiology, $78,245-255$.

Duvenage, S., \& Korsten, L. (2017). Assessment of foodborne pathogen presence in the peach supply chain and its potential risk to the end consumer. Food Control, 78 374-382.

van Dyk, B., de Bruin, W., Du Plessis, E., \& Korsten, L. (2016). Microbiological food safety status of commercially produced tomatoes from production to marketing. Journal of Food Protection, 79(3), 392-406.

European Food Safety Authority. (2017). C163/01 Commission notice on guidance document on addressing microbiolgical risks in fresh fruits and vegetables at primary production through food hygiene. Official Journal of the European Union, 60(1), 1-40.

Food Standards Australia New Zealand, FSANZ. (2000). Australia New Zealand food standards Code - standard 3.2.2 - food safety practices and general requirements. Canberra. Viewed 25th February 2020 https://www.legislation.gov.au/Details/F2 014 C01204.

Food Standards Australia New Zealand, FSANZ. (2010). Microbiological survey of fresh horticultural produce in Australia, 2005-2007. Canberra.

Food Standards Australia New Zealand, FSANZ. (2020). P1052 primary production and processing requirements for high-risk horticulture. Supporting document 1, microbiological assessment approach and foodborne illness summary.

Food and Agriculture Organisatio, World Health Organisation, FAO/WHO. (1999). Recommended international Code of practice general principles of food hygiene. Rome, CAC/RCP 1-1969, Rev 4-2003: 1-31 http://www.fao.org/3/w8088e/w80 88e04.htm.

Food and Agriculture Organisation, World Health Organisation, FAO/WHO. (2003). Code of hygienic practice for fresh fruits and vegetables. Rome http://www.fao.org/ ag/agn/CDfruits_en/others/docs/alinorm03a.pdf.

Food and Agriculture Organisation, World Health Organisation, FAO/WHO. (2008). In Microbiological hazards in fresh fruits and vegetables. Microbiological risk assessment series 14, meeting report. Rome. https://www.who.int/foodsafety/publications /mra_14/en/.

Food and Drug Administration, U.S. Department of Health and Human Services, FDA and DoHHS. (1998). Guide to minimise microbial food safety hazards for fresh fruits and vegetables. https://www.fda.gov/regulatory-information/search-fda-guidance-doc uments/guidance-industry-guide-minimize-microbial-food-safety-hazards-fresh-cutfruits-and-vegetables.

Food and Drug Administration, U.S. Department of Health and Human Services, FDA and DoHHS. (2016). food safety modernisation act produce safety rule. https://www.fda. gov/regulatory-information/search-fda-guidance-documents/guidance-industryguide-minimize-microbial-food-safety-hazards-fresh-cut-fruits-and-vegetables.

Fresh Produce Safety Centre, Australia \& New Zealand, FPSC. (2019). Guidelines for fresh produce food safety. https://fpsc-anz.com/food-safety-guidelines-2019/.

Freshcare. (2019). Food safety and quality edition, 4.1 p. 48). Freshcare Ltd. https://www. freshcare.com.au/product/fsq-manual/.

Gagliardi, J. V., Millner, P. D., Lester, G., \& Ingram, D. (2003). On-farm and postharvest processing sources of bacterial contamination to melon rinds. Journal of Food Protection, 66(1), 82-87.

Garner, D., \& Kathariou, S. (2016). Fresh produce-associated listeriosis outbreaks, sources of concern, teachable moments, and insights. Jourmal of Food Protection, 79 (2), 337-344.

Gibbs, R., Pingault, N., Mazzucchelli, T., O’Reilly, L., MacKenzie, B., Green, J., Mogyorosy, R., Stafford, R., Bell, R., Hiley, L., Fullerton, K., \& vanBuynder, P. (2009). An outbreak of Salmonella enterica serotype litchfield infection in Australia linked to consumption of contaminated papaya. Journal of Food Protection, 72(5), 1094-1098.

Gil, M. I., Selma, M. V., Lopez-Galvez, F., \& Allende, A. (2009). Fresh-cut product sanitation and wash water disinfection: Problems and solutions. International Journal of Food Microbiology, 134, 37-45.

Glass, K., Golden, M., Wanless, B., Bedale, W., \& Czuprynski, C. (2015). Growth of Listeria monocytogenes within a caramel coated apple microenvironment. mBio, 6 (5). e01232-01215.

GlobalGap. (2019). The GlobalG.A.P. Fruit and vegetables certification standard. v5.2 retrieved 25th February 2020 http://www.globalgap.org/.

Department of Agriculture, Western Australia. (2002). Guidelines for the management of microbial food safety in fruit packing houses. Bulletin, 4567 (Perth). 
Gomba, A., Chidamba, L., \& Korsten, L. (2016). Prevalence and serovar diversity of Salmonella spp. in primary horticultural fruit production environments. Food Control, 69, 13-19.

Horticulture Australia Ltd. (2016). Harmonised Australian retailers produce Scheme.

Horticulture Innovation Australia and Apple and Pear Australia Ltd, HIA and APAL. (2016). Aussie Apples Guidelines, specifications and product description language. Reference Guide.

Institute of Food Technologists and Food and Drug Administration, IFT and FDA. (2001). Analysis \& evaluation of preventive control measures for the control \& reduction/ elimination of microbial hazards on fresh \& fresh-cut produce. Viewed 22nd November 2019 www.fda.gov/Food/FoodScienceResearch/SafePracticesforFood Processes/ucm090977.htm.

Jacxsens, L., Kussaga, J., Luning, P. A., Van der Spiegel, M., Devlieghere, F., \& Uyttendaele, M. (2009). A microbial assessment scheme to support microbial performance measurements of food safety management systems. International Journal of Food Microbiology, 134, 113-125.

Jay, S., Davos, D., Dundas, M., Frankish, E., \& Lightfoot, D. (2003). Chapter 8: Salmonella. Foodborne microorganisms of public Health significance. A. D. Hocking. Waterloo, NSW, AIFST, Inc. NSW Branch.

Kenney, S. J., Burnett, S. L., \& Beuchat, L. R. (2001). Location of Escherichia coli O157: $\mathrm{H7}$ on and in apples as affected by bruising, washing, and rubbing. Journal of Food Protection, 64(9), 1328-1333.

Kilonzo, C., Li, X., Vivas, E., Jay-Russell, M. T., Fernandez, K. L., \& Atwill, E. R. (2013) Fecal shedding of zoonotic food-borne pathogens by wild rodents in a major agricultural region of the central California coast. Applied and Environmental Microbiology, 79(20), 6337-6344.

Kirezieva, K., Nanyunja, J., Jacxsens, L., van der Vorst, J. G. A. J., Uyttendaele, M., \& Luning, P. A. (2013). Context factors affecting design and operation of food safety management systems in the fresh produce chain. Trends in Food Science \& Technology, 32(2), 108-127.

Kruskal, W., \& Wallis, W. A. (1952). Use of ranks in one-criterion variance analysis. Journal of the American Statistical Association, 47(260), 583-621.

Kumar, C. G., \& Anand, S. K. (1998). Significance of microbial biofilms in food industry: A review. International Journal of Food Microbiology, 42(1), 9-27.

Kumar, G., Williams, R., Al Qublan, H., \& Sriranganathan, N. (2017). Airborne soil particulates as vehicles for Salmonella contamination of Tomatoes. International Journal of Food Microbiology, 243, 90-95.

Leverentz, B., Conway, W., Camp, M., Janisiewicz, W., Abuladze, T., Yang, M., Saftner, R., \& Sulakvelidze, A. (2003). Biocontrol of Listeria monocytogenes on freshcut produce by treatment with lytic bacteriophages and a bacteriocin. Applied and Environmental Microbiology, 69(8), 4519-4526.

Luning, P. A., Bango, 1., Kussaga, J., Rovira, J., \& Marcelis, W. J. (2008). Comprehensive analysis and differentiated assessment of food safety control systems: A diagnostic instrument. Trends in Food Science \& Technology, 19, 522-534.

Luning, P. A., Marcelis, W. J., Rovira, J., Van der Spiegel, M., Uyttendaele, M., \& Jacxsens, L. (2009). Systematic assessment of core assurance activities in a company specific food safety management system. Trends in Food Science \& Technology, 20, 300-312.

Macarisin, D., Sheth, I., Hur, M., Wooten, A., Kwon, H. J., Gao, Z., De Jesus, A., Jurick, W., II, \& Chen, Y. (2019). Survival of outbreak, food and environmental strains of Listeria monocytogenes on whole apples as affected by cultivar and wax coating. Scientific Reports, 9(12170), 1-11.

Machado-Moreira, B., Richards, K., Brennan, F., Abram, F., \& Burgess, C. M. (2019). Microbial contamination of fresh produce: What, where and how? Comprehensive Reviews in Food Science and Food Safety, 18, 1727-1750.

Meerburg, B. G., Singleton, G. R., \& Kijlstra, A. (2009). Rodent-borne diseases and their risks for public health. Critical Reviews in Microbiology, 35(3), 221-270.

Munnoch, S. A., Ward, K., Sheridan, S., Fitzsimmons, G. J., Shadbolt, C. T., Piispanen, J. P., Wang, Q., Ward, T. J., Worgan, T. L. M., Oxenford, C., Musto, J. A., McAnulty, J., \& Durrheim, D. N. (2009). A multi-state outbreak of Salmonella Saintpaul in Australia associated with cantaloupe. Epidemiology and Infection, 137(3), 367-374.
Pahl, D. M., Telias, A., Newell, M., Ottesen, A., \& Walsh, C. (2013). Comparing source of agricultural water and the presence of faecal indicator organisms on the surface of 'juliet' grape tomatoes. Journal of Food Protection, 76(6), 967-974.

Park, S., Szonyi, B., Gautam, R., Nightingale, K., \& Ivanek, R. (2012). Risk factors for microbial contamination in fruits and vegetables at the preharvest level: A systematic review. Journal of Food Protection, 75(11), 2055-2081.

Premier, R., \& Ledger, S. (2006). Good agricultural practices in Australia and southeast asia. HortTechnology, 16(4), 552-555.

Riordan, D., Sapers, G., \& Annous, B. A. (2000). The survival of Escherichia coli O157:H7 in the presence of Penicillium expansum and glomerella cingulata in wounds on apple surfaces. Journal of Food Protection, 63(12).

Ryu, J.-H., \& Beuchat, L. R. (2005). Biofilm formation by Escherichia coli 0157:H7 on stainless steel: Effect of exopolysaccharide and curli production on its resistance to chlorine. Applied and Environmental Microbiology, 75(1), 247-254.

Salazar, J., Carstens, C., Bathija, V., Narula, S., Parish, M., \& Tortorello, M. L. (2016). Fate of Listeria monocytogenes in fresh apples and caramel apples. Journal of Food Protection, 79(5), 696-702.

Smilanick, J. (2003). use of ozone in storage and packing facilities. Washington tree fruit postharvest conference. Wenatchee, Washington, Washington State University TFREC Postharvest Information Network.

Suslow, T. V. (1997). Chlorination in the production and postharvest handling or fresh fruits and vegetables. Post harvest chlorination. Basic properties and key points for effectivedisinfection. University of California. Publication 8003.

Suslow, T., Oria, M., Beuchat, L., Garrett, E., Parish, M., Harris, L., Farber, J., \& Busta, F. (2003). Ch II production practices as risk factors in microbial food safety of fresh and fresh-cut produce. Comprehensive Reviews in Food Science and Food Safety, 2. supplement 1.

Sutherland, S., Miles, D., \& Laboyrie, D. (2003). Chapter 13 Listeria monocytogenes. Foodborne microorganisms of public Health significance. NSW, AIFST: A. D. Hocking. Waterloo.

Sydney Harris, L. J., Farber, J. N., Beuchat, L. R., Parish, M. E., Suslow, T. V., Garrett, E. H., \& Busta, F. F. (2003). Chapter III outbreaks associated with fresh produce: Incidence, growth and survival of pathogens in fresh and fresh-cut produce. Comprehensive Reviews in Food Science and Food Safety, 2, 78-141. Supplement.

Taylor, T. M., Sofos, J. N., Bodnaruk, P., \& Acuff, G. R. (2015). Chapter 2. Sampling plans, sample collection, shipment and preparation for analysis. Compendium of methods for the microbiological examination of foods. American Public Health Association.

Uchima, C., de Castro, M., Gallo, C., Rezende, A., Benato, E., \& Penteado, A. (2008). Incidence and growth of Listeria monocytogenes in persimmon (Diaspyros kaki) fruit. International Journal of Food Microbiology, 128, 235-239.

United Fresh Produce Association, UFPA. (2018). Guidance on environmental monitoring and control of Listeria for the fresh produce industry. Retrieved 5th January 2020 https://protect-au.mimecast.com/s/pJEJCk8vzVfyg4X1UkifOS?dom ain $=$ info.unitedfresh.org.

United States Department of Agriculture, USDA. (2002). United States standards for grades of apples, 1-13. Retrieved 11th November 2019 https://www.ams.usda.gov/ sites/default/files/media/Apple_Standards.pdf.

Won, G., Schlegel, P., Schrock, J., \& LeJeune, J. (2013). Absence of direct association between coliforms and Escherichia coli in irrigation water and on produce. Journal of Food Protection, 76(6), 959-966.

Woolworths Limited. (2013). Woolworths quality assurance standard, WQA. Appendix 2: Microbiological and chemical requirements, woolworths Ltd. 8: 1-14. Viewed 1st April 2017 https://www.wowlink.com.au/cmgt/wcm/connect/aad00b80433d 393e8a199aa521a80a40/201300512+WQA +Produce+Standard+Version+8.pdf? MOD=AJPERES

Wu, J., Gao, H., Zhao, L., Liao, X., Chen, F., Wang, Z., \& Hu, X. (2007). Chemical compositional characterization of some apple cultivars. Food Chemistry, 103, 88-93.

Xu, A., Pahl, D. M., Buchanan, R. L., \& Micallef, S. A. (2015). Comparing the microbiological status of pre- and postharvest produce from small organic production. Journal of Food Protection, 78(6), 1072-1080. 